\title{
Critical Thinking among Pre-service Teacher Trainees: A Review Using 5 -Step Framework
}

\author{
Moalosi, W.T.S., Mgawi, R.K., \& Moeti, B. \\ University of Botswana, Botswana
}

\author{
Received: Oct. 10, 2016 Accepted: Oct 31, 2016 Published: November 1, 2016 \\ doi:10.5296/jse.v6i4.10481 URL: http://dx.doi.org/10.5296/jse.v6i4.10481
}

\begin{abstract}
Critical thinking has been perceived as a critical and important skill by educators, although it is not clear how useful it can be when incorporated in the college curriculum. The job market and education in general view critical thinking as an essential skill at work and during training. Apart from subject competencies, higher learning institutions (HLIs) are challenged to produce graduates that can think critically. The focus of this paper is to examine responses of Postgraduate Diploma of Education Students (PGDE) on critical thinking in relation to the 5 Step- Framework. A qualitative research was conducted at the University of Botswana and data was collected through one-on-one interviews and focus group discussions among 59 students. The discussion in this paper is a comparison of the responses of PGDE students on their views of critical thinking and 5 Step - Model. Thematic content analysis was used to analyse the data and findings revealed that, the PGDE students lacked critical thinking abilities during their training. Among other strategies, teacher methods and techniques were identified as factors that influenced critical thinking among the students. The participants also cited curriculum design and lack of motivation as creating a negative impact on their ability to think critically. Review of literature on factors influence critical thinking indicated that, in many cases lecturers have concentrated on subject matter and course content instead of methods and techniques that can help develop critical thinking skills on students. Further, the literature review shows the need to develop models, innovations, methods and techniques that can promote critical thinking among college students.
\end{abstract}

Keywords: Critical thinking, Postgraduate Diploma in Education, teaching methods, teaching techniques 5-Step Framework 


\section{Introduction}

The government of Botswana has always aimed for quality education to her citizens as reflected from National Commission on Education reports of 1993 and 2008/9. Botswana's strategy for education and training into the $21^{\text {st }}$ century is quoted "to improve general education so as to prepare students more effectively for life and citizenship and the world of work 1993. p.vi". The Ministry of Education Strategic Plan 2001-2006 (Botswana) also reads, "To offer equitable lifelong education and training that is relevant and responsive to the rapid technological development and the changing socio economic environment, and that produces knowledgeable, skilled and independent individuals"

Botswana has celebrated 50 years of independence, this year (2016) from the British protection. Botswana, by then was called Bechuanaland Protectorate. Since 1966 to date, the training of teachers has been at the heart of the Government. Programmes has been developed National Policies on Education to meet the standards of quality Education. However, research conducted with PGDE students, can make an individual to wonder, in regard to the critical thinking abilities of the teacher trainees. Dibapile, (2005) analysed the reasons offered by the PGDE students in the University of Botswana for choosing teaching as a career. Altruistic reasons, choosing teaching as a profession because, they wanted to reduce shortage of teachers because they felt that expatriates teachers were many teaching in secondary schools in their country.

Extrinsic reasons dominated the responses of the teacher trainees, extrinsic reasons hast to do with other external offers of the job, for example, school holidays, social status of the job and salary structure. The implication is, the teacher trainees did not have the desire to impact knowledge to the learner (intrinsic reasons) as their priority to embark in the teaching profession. On contrary, they gave priority to the comfort they can get from the job (extrinsic reasons). Such convictions mentioned above do not convince that the PGDE students did think critical in relation to opting teaching as a carrier.

Research findings with Botswana pre-service and in-service teachers have reported a low teacher efficacy in relation to student engagement, classroom management and instructional strategies. Dibapile, (2011), Moalosi, 2015, Moalosi and Forcheh, 2015). It is then call on research to investigate more on models that can enhance critical thinking skills. Because if a teacher shows that she/he lack information and skills to engage students in learning, deal with unruly behaviour in the classroom as well as a failure to employ different methods of learning need to be exposed to innovations that can enhance their critical thinking. Also in relation to the training of teachers the National Commission of Education (1977) showed concern

Teaching is regarded as a profession of low status in Botswana and some Batswana enter teaching as a second or third choice or because nothing is available. For as long as this attitude remains people of the required quality will not be attracted into teaching (p 5-6).

It is crystal clear that the training of teachers is the cream of Botswana government, and efforts have been made to put in practice the training of teachers. There have been improvements even in upgrading the Teacher Training programmes from certificate courses 
to diplomas and degrees. For example, Serowe, Molepolole, Tonota and other colleges now offer Diploma programmes. It is to ensure that quality education is being maintained in training pre- service teachers. Though such efforts are put in place it is not known whether teacher trainees have the ability to think critically, are they knowledgeable enough? Do they have enough skills for critical thinking and the ability to influence students' in the learning environments?

\section{Critical thinking is defined below}

The Vision 2016 of Botswana states an educated and informed nation. If PGDE students in the University of Botswana are perceived as educated and informed, they should develop more their critical thinking skills. Critical is regarded "as an important component of many medium- high- complexity jobs” Huber and Kuncel, (2016. p. 431).

The word critical is taken from the Latin language meaning "criticus" the ability to do evaluation. Klein (as cited in Kitot, Ahmad, and Seman (2010). Chance (as cited in Huitt, (1998 p.1) added that critical thinking is ... "the ability to analyse facts, generate and organize ideas, defend opinions, make comparisons, draw inferences, evaluate arguments and solve problems". Critical thinking is viewed as not similar with intelligence, hence a skill that needs improvement in individuals. Also normal thinking is not critical thinking. Critical thinking needs "higher mental functions" Vygotsky (1978) stated. Critical thinking is complicated also as it is constructed on standards of "objectivity and subjectivity". It is important to teach students to "change their thinking from (a) guessing to estimating, (b) preferring to evaluating, (c) grouping to classifying, (d) believing to assuming, (e) inferring to inferring logically, (f) associating concepts to grasping principles, (g) noting relationships to noting relationships among relationships, (h) supposing hypothesis to hypothesizing, (i) offering opinions without reasons to offering opinions with reasons and (j) making judgements without criteria to making judgements with criteria" Moore, (2015 p.378).

The mentioned above categories of critical thinking shows that students need to engage their mental process if they have to perform very well in learning. Critical thinking need advanced thought processes, where students can evaluate, synthesis rather applying or analysing concepts (Moore, 2015).

\section{Literature Review of Critical thinking}

Critical thinking is needed elsewhere; Botswana is not the only country that wants its students to develop higher levels of thinking. It is evident that South Africa 's recent reforms are ... characterised by the ideals that the country needs to produce independent, critical thinkers who are able to question, weigh evidence, make informed judgements and accept incomplete nature of Knowledge (Republic of South Africa (RSA), 1995: 22). Education system in Malaysia, like Botswana also "aims to produce students who are able to think, be knowledgeable in many areas, and have profound knowledge in ICT Kitot, Ahmad, Seman, (2010 p.263). It is interesting that Curriculum Development Centre (CDC) in Malaysia is developing approaches that stresses student-centred learning as seem to encourage critical 
thinking to shun traditional methods (teacher-centred approaches) that students become recipients of information without " taking into consideration their ability to think" (. 263).

Thailand researchers from 1982 to 2004 have investigated variables that are related to critical thinking. Their research findings showed concern in relation to the development of critical thinking among students and they used different strategies as well as "formats" to enhance critical thinking Mahapoonyanont, (2012). The 2004 meta-analysis study of Mahapoonyanont identified factors related to critical thinking skills since 1982 as, "teaching factors, student factors and personal factors and child-rearing/training"( p.147). It shows from research findings that there is a need to conduct research influencing students to think critically. Some students may have those skills of thinking critically but they may be some hindrances from different environments.

This writer argues that the Post-Graduate Diploma of Education (PGDE) pre-service may encounter challenges in relation to critical thinking. The experience of the writer who has taught PGDE students in the University of Botswana have seen lack or participation of these students. They are reluctant in relation to communicating their thoughts. Large classes are a challenge too class size range from 80 to 100 . The writer does not know if large classes can influence critical thinking with these students.

The other disadvantage of teaching large classes is they can increase teacher centred approaches, where the teacher is overwhelmed by many students she the is teaching and does not have enough time of helping individuals who may be struggling as they learn. Students who are exposed to teacher- centred methods of teaching tend to be recipients of information from the teacher without considering their thinking capabilities. This reduces the students' potential to think and it enables them to "receive instructions without doing any analysis and synthesis" Kitot, et al. (2010 p.263).

Students should develop metacognition strategies to enhance their thinking. Metacognition can assist students' critical thinking abilities. Metacognition as described by Moore, (2015) is "thinking about thinking" and skills related to thinking are called metacognitive skills. Seifert,(2012) concurred that, metacognition are strategies requires an individual to think about thinking as well being engaged in monitoring the progress and quality of an individual's thinking.

\section{Factors influencing critical thinking}

The research literature of critical thinking implies that, critical thinking is related to "reasonable, reflective thinking, focusing on task, people or belief". Accordingly, the descriptions of critical thinking do not include creative thinking Pitchers and Sodden, 2000). The importance of individuals focusing on tasks and beliefs on themselves in their professions is vital in every discipline in the world because there will be evident of performance and good results in the world of work. Critical thinking and factors that influence it are a concern elsewhere, which is the reason of conducting the present research because the results of the study can inform education in general about lack of critical thinking among pre-service. 
Teacher methods in institutions that train teachers have been perceived as factors that can influence critical thinking among students. Also, curriculum designed by some college and university lecturers can have a negative impact on students' failure to thinking critically Kember, (1997). For example, if lecturers concentrate on subject matter and course contents only, instead of developing critical skills on students there will be no opportunities for students to think critically. Research findings in the departments of Education in the United Kingdom, in the 1980's advocated for improvement of thinking in regard to work related issues, and teaching strategies to improve critical thinking were not implemented or found in Social Care courses. Hence the Social Care courses were introduction to careers that esteem critical thinking. Bloomer (as cited in Pithers and Soden, (2000) reported similar results with programmes of General National Vocational Qualifications (GNVQ). Also, lack of published work that addresses the development of critical thinking in courses that are offered at degree levels are a concern (Pithers and Soden, (2000). Critical thinking seems to be a difficult concept among lecturers and students. The investigations on critical thinking as reported by Pithers and Soden (2000) with degree courses showed that, "lecturers, tutors and students seemed not to share an understanding of what it means to think critically (p. 240).

Research evidence has revealed some practices that can hinder critical thinking among students. Published literature of the past, on teaching thinking had focused on strategies which prevented rather than encouraging "good thinking". Raths et.Al (as cited in Pithers and Soden, (2000) defined the relationship between thinking and behaviours and reported that, some students's "thoughtless or unwise" behaviours are the major behavioural characteristics. The researchers advocated for change in the negative behaviours of students to positive outcomes. Rats and his colleagues identified teacher-student collaboration as the channel is which thinking could be enhanced very well.

Their research evidence proposed eight behaviour forms they called "types" which implied lasting and irreversible student qualities that classified shortfalls in good thinking among learners who: (1) act without thinking (impulse); (2) need help at each step (over dependent); (3) use goal- incompatible strategies (do not perceive cause - effect relationships); (4) have difficulty with comprehension (miss meaning) ; (5) are convinced of the "'rightness of their beliefs (dogmatism) (6) operate within narrow rule sets (rigidity/inflexibility); (7) are fearful ( not confident); and (8) condemn good thinking as a waste of time (anti-intellectual) (p.242). This writer has observed some on the mentioned above behaviours withlarge classes she isteaching in her institute. Students in her lectures tend to be noisy and over dependent that even when given assignments to work in groups they are so reluctant and always having expectations of receiving information from the lecturer. They need to be pushed to be engaged in activities as they learn. Thus, critical thinking attributes should be encouraged among such students. Pithers and Soden (2000) asserted "evidence that students enter higher education with underdeveloped ability to think critically is another argument for finding effective measures to promote this ability" (p.240). Critical thinking needs individual to possess skills of analysing the "reliability and validity of information" Seifert (2012 p. 161).An individual who thinks critically needs not to have "a negative attitude in the everyday sense of constantly criticizing someone or something” Seifert (p.161). 


\section{Theoretical Frame work}

Critical thinking has been perceived as vital and essential as it is needed in the workplace. It can assist trainee teacher to be in contact with their cognitive abilities and "spiritual questions, and it can be used to evaluate people, policies, and institutions, thereby avoiding social problems" Hatcher and Spencer (as cited in Duron, Limbic\& Waugh (2006).

The present discussion is guided by the 5-Step Model to enable students to think critically. However, it is crystal clear from the research on the literature review of Lai (2011) that, critical thinking in the educational settings is embedded in the work of Benjamin Bloom (1956). Educators have discussed and employed the taxonomy in their work. And when they teach and evaluate 'higher order thinking skills' they use Bloom's taxonomy. The taxonomy is in categories, analysis, synthesis and evaluation are in the highest level are signifies critical thinking, while comprehension is at the bottom and the top. Kennedy (as cited in Lai, (2011). Ennis (1993) similarly stated that, "the higher three levels of Bloom's taxonomy of educational objectives (analysis, synthesis and evaluation) are often defined offered a definition of critical thinking" (p. 179).

Individuals who use the lower level of the taxonomy will engage in less thinking while using higher levels will be expected to engage in more or advanced thinking. Duron, et al. (2006). It is interesting to find out that, if teachers they have to assist their students in learning they should enable them to use the highest levels of Bloom's taxonomy. Albrecht and Sack (as cited in Duron, et al. stated that, while many teachers have the belief that it is their responsibility to develop thinking among their students, not many of them know what critical is and how to teach it as well as assessing critical thinking. Paul, Elder,\& Batell (as cited in Duron et al.(2006). Therefore, the frame work, 5- Step model, can be applied "in any classroom or training setting to help student gain critical thinking skills (p.161).The model is discussed in comparison to the responses from interviews of PGDE students in the University of Botswana.

Step1: Determine learning Objectives. Teachers in any program or course they ought to identify the major learning objectives that explain the behaviours students need to display when they leave the classroom. In order for critical thinking to occur the learning objectives and the intended activities and evaluations have to involve those related to the higher levels of Blooms Taxonomy Duron et al. (2006). Learning objectives are important aspects of the lesson. For example, the first characteristics of a Direct Instruction lesson expect teachers to "State learning objectives and orient students to the lesson" (Slavin, 2012 p. 185). The teaching profession has shift from traditional methods of teacher centeredness to student centred approaches, therefore students should be informed in the classroom settings what they will be learning and expectations of their performances.

Some of the students' expressions when interviewed show that, students' thinking is not provoked for learning. Their appetites for the lesson are not challenged. Slavin (2012) stated that, students should be informed how interesting the lesson will be, and how the lesson and the relevance of the lesson to them as individuals. When students are made aware of the 
important of the lesson there is no way that, they can communicate lack of passion during training.

Excerpt 1:"Some students say they are not interested in the PGDE program, but they do it as a cover up, some have no passion, they don't want to stay at home. We really need to be taught to be critical thinkers".

Except 2: "Teachers need a critical thinking course because they are going to help the students in the community".

Excerpt 3: "PGDE students are like passengers in a bus, they are not interested in the program”.

Excerpt 4: 'Course structure doesn't allow one to express him/herself',

The mentioned above expressions of students from the interviews about critical thinking show that, the learning objectives may not be explained in details for students to be involved in the their work hence their negative responses. And if they are discussed in details to students, they can be develop motivations in their program, be engaged in the teaching program and be passionate about their decisions to embark in the teaching profession. The desperations for students to desire to be taught how to think critically can be an implication that, defining the behaviours students ought to demonstrate when they leave classrooms may be lacking, or they can be exposed to such behaviours but may not be putting more effort.

Step 2: Teach through questioning. Questioning method is essential in the teacher's instruction. It is an important aspect in the teaching and learning environment. Questions permit the teacher to institute what the students know and then expand more on developing students' new ideas Duron et al. Accordingly, questions can be used to facilitate the interaction of the teacher and students and to "challenge the learner to defend his or her position, (i.e., to think critically" p.162). Questioning students during learning is perceived as an assessment in relation to the level of understanding for students as well correcting them where they do not understand concepts Slavin, (2012).

Excerpt 5: The type of questions that we are given most of the time do not allow us to think critically for example, multiple choice and True and False statement are objective, you are directed to the answer you can't think out of the box.

Step 3: Practice before you assess. Students should be given the opportunity to practice what they have learned before they can be an evaluated on what they have learnt. Independent practice, as suggested by Slavin, (2012) should be provided to students, so that they can put in practice new skills they have learnt or use new information for their personal use. Historically, there has been a change that has occurred in education.

The change is active learning. Teachers, who have used the active learning strategy, have found that students have developed more interest in learning and enjoy the courses. Active learning as defined by Bonwell and Eison (as cited in Duron et al) "is involving the students in activities that cause them to think about what they are doing (p.162). Active learning has been viewed as supporting research that implies that learners learn better and they keep the 
information for a long time in their minds if they get in a an active form than passive. Fink (as cited in Duron et al.).

Excerpt6: Lecturers are soft with PGDE students; they give students marks even if when answers are wrong.

"Group work: When you are given an assignment you are going to think as an individual, you are going to research and do work alone, but with group work you rely on others”.

“Group work doesn't provide much critical thinking”.

"Some classes are too large the lecturer comes to class to deliver and go, we take the knowledge he gives to us, we just take what the gives to us, and we just receive what he gives us. If the class was small we could do what he gives to us".

''Time, course load too many, applying critical because unlimited running after course load',

Step 4: Review, refine, and improve. Teachers should keep on improving their courses to make sure that, their instructional strategies are assisting students to acquire critical thinking skills. To achieve that, teachers should be able to check if activities in the classroom are related. When teachers monitor the participation of students, they can keep a teaching diary that shows the students who took part in class activities and evaluate their progress. The teachers' observations can be seen in the diary and can be a very useful source when re-defining instructional objectives. The feedback teachers get from students are perceived as vital in relation to improving courses Duron et al.

“PGDE programme should be reviewed it can be made a 2 year program”.

“PGDE students depend on group work, some students don't come to groups they depend on the work of other students. Students alternate for both two semesters, they are divided into groups and exchange assignments".

Step 5: Provide feedback and assessment of learning. The teacher's evaluation, for example, assessment is to ensure that quality work and learning progress in maintained in the performance of students. Thus the aim of evaluating the student's learning is to increase quality as students learn contrary to giving them tests to evaluate their performance. Giving students feedback is vital because it gives the students opportunity to assess their continuing performance. Accordingly, evaluating students' performance gives the teacher and students' the opportunity "to engage in dialogue about what distinguishes successful performance from unsuccessful performance as they discuss criteria and standards" Fink (as cited in Duron et al p. 163).

"Some classes are too large the lecturer comes to class to deliver and go, we take the knowledge he gives to us, we just take what the gives to us, and we just receive what he gives us. If the class was small we could do what he gives to us.

"Presentations: Structures of presentations are teacher centred, interfering with students' intentions, allow students to continue with what they are planning to do, to own it”. 
"If you bring what you prepared the lecturer say we don't have time”.

"Grading, structure of assessment or rubrics should change”.

\section{Conclusion}

Critical thinking is the in-thing. Institutions universally share burdens of having trainees that do not match the expectations of the market place due to their inability to think critically. Research evidence reveal a concern where college students enter training with limited critical thinking skills. It is also pathetic because both students and lecturers seem not to understand what critical thinking is. The world of market at large admire students who can analyse and evaluate their intellectual abilities, but it is contrary as some students opt their vocation because of pressures of unemployment and they buy time rather than prioritising their career choices. Factors that hinder critical thinking cannot be ignored .Teaching; student child rearing/ training are such factors. Cultural factors in Botswana, where traditionally a child in the family is not expected to answer back during conversation but to agree with what parents/elders say can hinder critically thinking. Thus, thinking critically and communicate one's intentions is not much expected. Such a culture of communication the child will bring it to the classroom. Childhood experiences affect personality teachers within the African cultures should be aware of that and enhance critical thinking skills of learners.

This writer is convinced that critical thinking 5Step Frame Work should be incorporated in the curriculum to enhance critical thinking of teacher trainees. Some of the expressions of PGDE students show that critical thinking is hindered by many factors. For example, large classes prevent students from engaging in learning as well as in the activities they are expected to participate in. It is important to improve the training of teachers, but what is vital is what happens in the classroom. The characteristics of Five step- model can promote critical thinking among students when applied with different instructional strategies can enhance critical thinking among students. Institutions that train teachers should teach for cognitive education.

Metacognition, "thinking about thinking" can raise awareness to pre-service teachers. Pre-service as adults entering the teaching profession should be in touch with their mental process rather always depending on their lecturers. Critical thinking is perceived as not easy because its Critical thinking it is formed on standards of "objectivity and subjectivity" hence the PGDE students preferred subjective when it comes to assessments. Sometimes lecturers may not know what suits them, but a clear communications of learning objectives as in Step 1 of the 5 Step- Frame work can solve some of misconceptions in the learning settings. However, in the academic world, be it lectures or students we owe it all to critical thinking skills that should be displayed sin our practice. Reflective practice is vital, "the process of conducting a critical self- examination of one's teaching” Eggen and Kauchach, (2013 p.12. During the training of teacher lecturers should take a critical eye to their practice and refrain from teacher dominant methods of teaching and engage students in learning. Pre-service teachers also, when they leave training should go in the field and evaluate their teaching practice whether what they are practicing benefit learners or not 


\section{References}

Dibapile, W.T.S. (2011). A report of the responses of Botswana Junior Secondary School Teachers on the three Subscales of Teachers' Sense of Efficacy Scale (TSES). Journal of International Education Research, and Learning, 8(2), 145-154.

Dibapile, W.T.S. (2005). An analysis of the reasons offered by post-graduate diploma of education students in Botswana for opting teaching as a career. Journal of College Teachingand Learning, 2(1), 75-86.

Duron, R., Limback, L., \& Waugh, W. (2006) Critical thinking framework for any discipline. International Journal of Teaching and Learning in Higher Education, 17(2), 160-166.

Eggen, P., \& Kauchak, D. (2013). Educational psychology: windows on classrooms, ninth edition. London, Pearson.

Ennis, R. (1993). Critical thinking Assessment. Theory and practice, 32(3). College of Education: The Ohio State university. https://doi.org/10.1080/00405849309543594

Huber, C.R., \& Kuncel, N. R. (2016). Does college teach critical thinking? A meta-analysis. Review of Educational Research, 86(2) 431-468.

Huitt, W. (1998). Critical thinking: An overview. Educational Psychology Interactive. Valdosta, GA: Valdosta State University.

Government of Botswana, Long Term Vision for Botswana. (2016). Towards prosperity for all. Botswana Government Printer, Gaborone.

Government of Botswana, Long Term Vision for Botswana. (2016). towards prosperity for all. Botswana Government Printer, Gaborone.

Kember, D. (1997). A reconceptualization of research into academics' conceptions of teaching. Learning and Instruction, 7(3), 255-275. https://doi.org/10.1016/S0959-4752(96)00028-X

Kitot, A.K.A., Ahmad,A.R., \& Seman,A.A. (2010). The effectiveness of inquiry inenhancing students' critical thinking. Procedia- Social and Behavioral Sciences, 7, 264-273. https://doi.org/10.1016/j.sbspro.2010.10.037

Mahapoonyanont, N. (2012). The casual model of some factors affecting critical thinking abilities. Procedia- Social and Behavioral Sciences, 46, 146-150. https://doi.org/10.1016/j.sbspro.2012.05.084

Moalosi, W. T. S. (2015). Pre-service Teachers' Self-efficacy Beliefs at the two Colleges of Botswana.British Journal of Education, Society and Behavioural Science, 9(3), 186-194. https://doi.org/10.9734/BJESBS/2015/13144

Moalosi, W.T.S., \& Forcheh, N. (2015). Self- efficacy levels and gender differentials among teacher trainees in the colleges of education in Botswana. Journal of Education and Learning, $4(3), 1-13$.

Moore, K.D. (2015). Effective instructional strategies, $4^{\text {th }}$ edition: From theory to practice. 
London, Sage.

Pithers, R. T., \& Soden, R. (2000). Educational Research, 42(3), 237-249.

Report on the national commission on education. (1993). Republic of Botswana, Government Printer, Gaborone, Botswana.

Republic of South Africa (RSA). (1995). White paper on education and training. Pretoria Government Printer.

Slavin, R (2012). Educational Psychology: Theory and practice. Pearson, London

Seifert, K. (2012). Educational Psychology. Houston, Texas Connexions.

Vygotsky, L. S. (1978). Mind in society: developing higher psychological process. London: Harvard University Press. 